\title{
The Size and Management Approaches of Firms in the Czech Republic
}

\author{
Ludvík Ladislav $^{1}$ Jindra Peterková $^{2}$ \\ ${ }^{1}$ VŠB - Technical University of Ostrava, Czech Republic \\ ${ }^{2}$ VŠB - Technical University of Ostrava, Czech Republic
}

\begin{abstract}
In entrepreneurial and enterprises field we can see signs of the phenomenon, which should be recognized - the world of large enterprises and the world of small enterprises become more distant. Changes of size in enterprises groups heighten over the past 5 to 7 years in intensity. The way of enterprise managing adapt to it. The aim of the paper is to characterize enterprise structure in the Czech Republic as well as newly appearing trend in managing and organizing companies. In the paper there will be use the official data (Czech Statistical Office), expert data and a research probe.
\end{abstract}

Keywords: the size of enterprise, network structures, holding structures, selfemploying firm

\section{The size of enterprise: large and small enterprises}

It is obvious that the concept of enterprise size has relative meaning, it has historically evolved, it was and it is changing. The scale of assessment of a large enterprise has enormously changed during the last 100 years - from approx. 1 billion USD of sales at the beginning of the 20th century to 200 billion at the end of the century. [1, 2] Increasing size of enterprise is associated with the possibility to better connection and it combines the technique, capital and people. It gives a chance to sustain partial and temporary losses in a better way. At present, it is associated with better control of the global market. It deals with preparations and realization of new and complicated products. Also the preparations of fundamental innovations become to this issue. It is an opportunity to employ highly specialized and skilled people for leading and creative functions in an enterprise etc. If we take a look at global entrepreneurial environment, we will find out that 50.000 enterprises take part in global operations. Dominant firms create roughly one fifth of them. They are remarkable for their exceptional size or superior intellectual and innovation performance.

\subsection{The size structure of enterprises in the Czech Republic}

There were more than 1.1 million businesses in 2011 in the Czech Republic that are active in entrepreneurship. This means that one company gets a share of 10 residents. Over the past five years 2007-2011, the number of active entrepreneurial subjects has increased by almost $24 \%$.The statistical distribution of enterprises by size groups is very uneven see fig. 1 . The biggest number is represented by micro-enterprises nearly $95 \%$. Small enterprises: 10-49 employees represent about $4 \%$, medium-sized enterprises $1 \%$. Only two enterprises out of a thousand belong to the group of large enterprises. Over the past five years, the most noticeable growth has been seen in the group of micro-enterprises more than $25 \%$, while enterprises without employ- 
ees have been increasing (an increase of $33 \%$ ). The remaining groups more or less have stayed the same in numbers.

\begin{tabular}{|c|c|c|c|c|c|c|}
\hline \multirow{2}{*}{\multicolumn{2}{|c|}{ Enterprises by size }} & \multicolumn{5}{|c|}{ Number of enterprises in particular years ") } \\
\hline & & \multirow{2}{*}{$\begin{array}{l}2007 \\
862171\end{array}$} & \multirow{2}{*}{$\begin{array}{l}2008 \\
999377\end{array}$} & \multirow{2}{*}{$\begin{array}{l}2009 \\
1031711\end{array}$} & \multirow{2}{*}{1059092} & \multirow{2}{*}{\begin{tabular}{|l}
2011 \\
1082453
\end{tabular}} \\
\hline $\begin{array}{l}\text { Micro } \\
\text { enterprises }\end{array}$ & $\begin{array}{l}0-9 \\
\text { employees }\end{array}$ & & & & & \\
\hline $\begin{array}{l}\text { Small } \\
\text { enterprises }\end{array}$ & $\begin{array}{l}10-49 \\
\text { employees }\end{array}$ & 46239 & 47692 & 46790 & 45966 & 45341 \\
\hline $\begin{array}{l}\text { Medium } \\
\text { enterprises }\end{array}$ & $\begin{array}{l}50-249 \\
\text { employees }\end{array}$ & 11709 & 12088 & 11658 & 11656 & 11548 \\
\hline $\begin{array}{l}\text { Large } \\
\text { enterprises }\end{array}$ & $\begin{array}{l}250 \text { and more } \\
\text { employees }\end{array}$ & 2143 & 2181 & 2063 & 2160 & 2220 \\
\hline \multicolumn{2}{|c|}{ The Czech Republic in total } & 922262 & 1061338 & 1092222 & 1118874 & 1141562 \\
\hline
\end{tabular}

Fig. 1: The development of quantity of enterprises by size groups [6].

1) Active enterprises which demon strated their size in the number of employees

\section{Management approaches in the Czech Republic}

At present, in our opinion, enterprise management is strongly influenced by the fact, whether it is a speculative or valueorientated focus of an entrepreneurial activity. It is estimated that the impacts of speculative entrepreneurship are major. The relation between investment and speculative use of financial capital is estimated in the world so that one dollar of real investments accounts for 39 dollars of speculative transactions. Speculative forms of entrepreneurship have come so far that they even tunnel their own firms. That can be considered as a pathological phenomenon of entrepreneurship. Entrepreneurial seriousness and the character of an entrepreneurial environment are thus damaged. The Czech Republic is not an exception.

Since the middle of the last century there has been a talk about big changes in organization and management of large enterprises. [3] There has been a discussion whether the pyramid in fig. 2 has to be lower with less floors, but in wider range, so that the information about opportunities could be collected, or a pyramid with narrower base so that more attention would be focused on the strategic concept of an enterprise. With the ad- vantage of information and communication technologies and with an emphasis on maximizing short-term profits, two layers have been crystallized in enterprise management. [4] The upper layer consists of power, strategic management and control functions, lower layer belongs to operational management.

\subsection{Network structures}

A type of network entrepreneurship brought expectations and hopes in relation to small and medium firms in Czech conditions (since the mid 90's). There was an opportunity to increase their economic potential and influence and also to use the local specifics of small entrepreneurship. The initial idea of a better competitiveness thanks to the profit of mutual interest of connected subjects in the network was very lucrative. There were great examples abroad, especially the clusters.

The original concept of equal opportunities for network members, however, gets a crack. Economically powerful entities take control over entrepreneurial network and become the core of network. The asymmetry deepens among network members [5]. The core, which organizes and controls the network, accumulates the maximum of profit, semi peripheral or peripheral network is forced to assume an increasing degree of market risk. Peripheral partners are granted access to the network when they accede to the dominant members. Credibility is converted into power pressure in the effort to exhaust the competitive potential of the non-dominant firms in fig. 2. We find other negative consequences of major core enterprises, e.g. labour market for their privileged position in the region may be an unwelcome burden on transport and other infrastructure etc. 


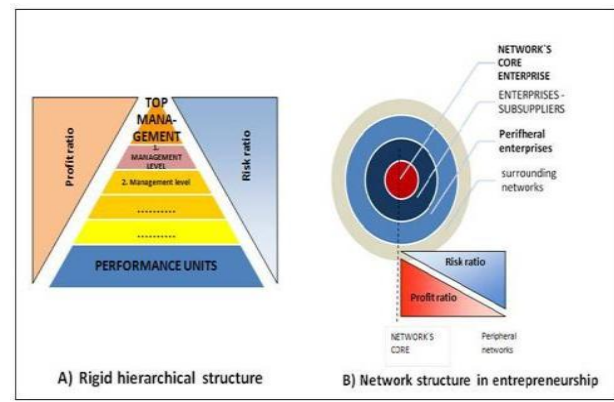

Fig. 2: Paradoxes in the management of solid and network structures in entrepreneurship, own processing.

\subsection{Holding structures}

We can see that three layers of holding structure have been gradually crystallized see fig. 3. The first form power, property and financial structure of the core holding. It consists of the parent company. Besides having the function of determining the share capital to control the other (subsidiary) companies, strategic function is focused on creating, renewal, transformation and expansion owned portfolio of the business and non-business type. Financial services for holding enterprises are considerable. There is also a central enclosure of holding group activities, e.g. in the form of purchases of selected items of goods, services, etc. This strategic "headquarters" is a separate legal entity.

The second layer consists of holding companies (daughters) of the first or further order. They are selected to a holding according to what the parent company prefers, whether it is financial (e.g. shortterm gain) or technological and marketing aspects (usually resource linking, technological, manufacturing and marketing verticals). These companies are legally separate entities.

Third - in fact added layer of the holding structure consist of a special type of non-profit organizations. Their mission is to create a favourable image of the holding company structure in the public eye. They can take the form of foundations, non-profit organizations, charitable activities. These can also be various fan clubs etc.

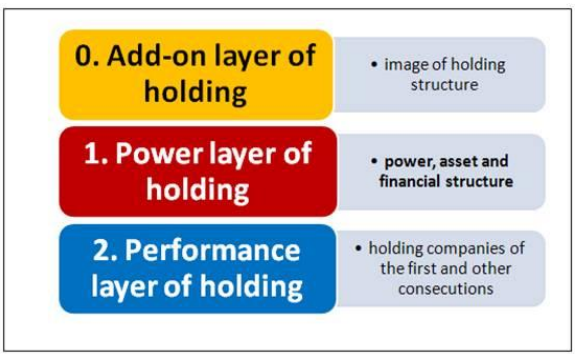

Fig. 3: Three levels of the holding structure, own processing.

\subsection{Self-employing firms}

However, when we have a look at the other size structures of enterprises, then there is the most numerous and very diverse group of self-employing firms (about $85 \%$ of the total number of firms). The subject of entrepreneurship outweigh simple activities, there are firms that focus on specialized and highly skilled and sophisticated activities. Knowledge of the control sphere is different - from the intuitively implemented control schemes to a funded enterprise models, corresponding knowledge of the micro-firms (usually these are independent consultants and advisers in business and management). A vital factor in management is the ability to communicate, cooperate, and collaborate.

We can observe a new phenomenon in the form of so-called Svarc system under the Czech conditions for 20 years. Czech entrepreneur named Svarc devised a way to save money on taxes and levies in particular social and health insurance. He began to implement his enterprise model so that all of his employees were laid-off. Then they began to work for the entrepreneur with a business license and supply agreement for a self-employed (Selfemployed). 


\section{Conclusion}

Under the conditions of the Czech Republic we can identify changes in size structure of the companies and in the actual approach to management at the particular sizes groups of enterprises. In the last five years there had grown the number of micro-firms ( $0-9$ employees) and in this group there are much more firms without employees.

Dominant and big enterprises are looking for the management approaches. They create conditions to keep their positions. They try to reach other markets and strengthen their economic and noneconomic influence. Dominant enterprises focus on organizational structure of the holding type. Holding is formed by controlling company and subsidiary companies that are controlled by controlling companies (controlling company has more than $50 \%$ of voting rights) or subsidiary companies that are under cocontrolled (controlling company owns directly or indirectly at least $20 \%$ but maximum $50 \%$ existing voting rights).

Subsidiary firms are selected to join holding based on techno-production or distribution verticals. Foreign enterprises create networks utilizing their dominant position. After the first wave of cluster initiative in the Czech Republic there appears stagnation. Some foreign enterprise branches that are dominant in these clusters are starting to think about leaving the entrepreneurial environment of the Czech Republic and relocate to Asian regions because of the costs reasons. It was found out that those members of branch formations endeavor the success of clusters especially under regional conditions. Innovations are the basic element in the area of uniqueness. In the managing process the most activities are oriented on cluster members rather than on activities connected with administrative agenda and contacts outside the cluster. The major group of the vital clusters was formed around big dominant enterprises.

The presented findings were generated under the project "Analysis and Demography of Enterprises in the Czech Republic".

\section{References}

[1] DONALD, F. K. Entrepreneurship: theory, process, practice. $1^{\text {st }}$. ed. 2009. ISBN 978-0-324-59091-3.

[2] JIRÁSEK, J. A. Agenda př́ístích let. 1. vyd. 2006. ISBN 80-86946-04-5.

[3] JIRÁSEK, J. A. Management budoucnosti, 1. vyd. 2008. ISBN 97880-86946-82-5.

[4] IRELAND, D.; HOSKISSON, R.; HIT, M. The Management of Strategy. $1^{\text {st }}$. ed. 2009. ISBN 978-0-538-753210 .

[5] KELLER, J. Tři sociální světy. 2. vyd. 2011. ISBN 978-80-7419-044-5.

[6] Offical Web of Czech Statistical Office. [online]. [cit. 2012 - 06]. http://www.czso.cz/eng/redakce.nsf/i/ home 